\title{
INFORMATION SYSTEM FOR MONITORING OF PREGNANT MOTHER IN RIAU PROVINCE HEALTH OFFICE
}

\author{
Mardeni \\ STMIK Hang Tuah Pekanbaru \\ mardeni1489@gmail.com
}

\begin{abstract}
The data collection of pregnant women is the realization of the Birth Planning and Prevention of Complications (P4K) Program in the Riau Provincial Health Office of the Family and Nutrition Health Section. The data collection of pregnant women aims to find out information about pregnant women scattered in 12 regencies and cities in Riau Province including: the number of pregnant women, Tabulin, transportation, blood donors, assisting pregnant women and birth assistance plans. Currently reports and data recording of pregnant women are still done manually using Excel. To make it easier for officers to monitor the health of pregnant women in Riau Province, a Web based health monitoring system for pregnant women was built. This system integrates data on pregnant women in Riau Province starting from the Puskesmas level. This system can help officials in the Health Department monitor and record pregnant women, so that they can assist in planning a safe delivery and preparing for complications for pregnant women..
\end{abstract}

Keywords: Health Monitoring, Pregnant Women, Information System.

\section{INTRODUCTION}

The Family Health and Nutrition Section through the Family Health program of the Riau Provincial Health Office, which has a Birth Planning and Complications Prevention Program (P4K) is one of the government's efforts to reduce maternal mortality (AKI) in Indonesia.

One of the main activities in the $\mathrm{P} 4 \mathrm{~K}$ program is to collect data and monitor pregnant women in the province of Riau. The data collection includes data on the number of pregnant women, maternity savings (Tabulin), blood donors, delivery assistance, transportation, and rescue plans.

At this time, all the activities in the monitoring and data collection program for pregnant women are still done manually using Microsoft Office Excel. Based on these problems the authors formulated to create an information system to monitor the health of pregnant women web-based(Sudirman, 2016). It is expected that this information system can provide facilities for health officials in regularly recording and monitoring pregnant women in Riau Province.

\section{LITERATURE REVIEW}

Strategic planning of information systems and information technology to support the success of the vision, mission and goals of the organization in the field of education, especially health so as to increase the need for information collection, storage and distribution quickly. This study uses a ward and peppard strategic / IS / IT planning framework, this stage starts from problem identification, data collection, analysis of the business and IS / IT external environment, analysis of the internal business environment and SI / IT, determining the IS / IT strategy including developing an application portfolio , hardware, software and network infrastructure proposals, IT HR proposals and conducting Gap analysis. Some tools used are PESTLE, Five Porter Theory, CSF, Value Chain, and McFarlan analysis. From this research, SI strategy planning, IT strategy planning and SI / IT management strategy planning are produced(Irawan, 2017).

The Family Health and nutrition section through the Family Health program, which has a Childbirth Planning and Prevention Complications Program (P4K) is one of the government's efforts to reduce maternal mortality (AKI) in Indonesia. P4K program efforts have begun around 2010, but until now the aim to reducing the MMR stated in the MDGs by 102 per 100,000 live births in 2015 has not been achieved(Indonesia, M. P., \& Kemiskinan, U. P., 2015).

According to the 2012 IDHS, MMR in Indonesia actually experienced an increase of 359 per $100,000 \mathrm{KH}$. P4K is an activity facilitated by the village midwife in order to increase the 
active role of her husband, family and community in planning a safe delivery and preparation for complications for pregnant women.

What has been achieved is the recording of the number of pregnant women, ie each cadre has the obligation to record if there are pregnant women and then the Midwife reports during the posyandu. Maternity Savings (Tabulin), cadres collect funds from every pregnant woman in every posyandu area. Blood donors, cadres tell pregnant women and families the need for blood donor preparation if at any time the pregnant woman is operating or bleeding, for checking blood groups from family or community(Fadilah, N., \& McKenna, L., 2019).

Assistance, cadres have conveyed the need for assistance, especially if the mother is referred, assistance is usually done by her husband and family. Relief plan, All pregnant women are assisted by village midwives during childbirth. Transport or Village Ambulances, if a car is needed all community members who have a car are willing, if there is no special car for village ambulances. And sticking stickers, sticking stickers by cadres and sometimes by Mrs. Midwife. (Kamidah,2018).

\section{RESEARCH METHOD}

The method used in this study is the waterfall method. The reason for using this method is because the waterfall method approaches systematically and sequentially in building a system. The waterfall method process is the work of a system carried out sequentially(Kadir, 2014). The resulting system will be of good quality, because the implementation is gradual so it is not focused on certain stages(Darmawan, et. al., 2013).

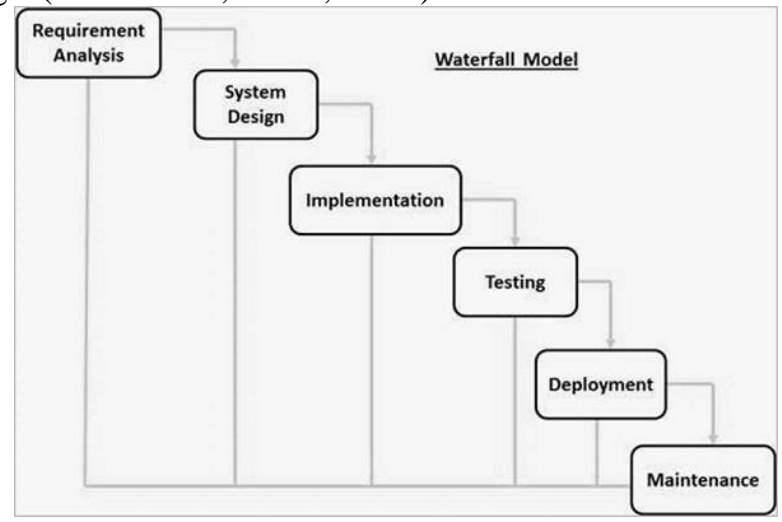

Figure 1. Waterfall Model

- Requirement Gathering and analysis - All possible requirements of the system to be developed are captured in this phase and documented in a requirement specification document.

- System Design - The requirement specifications from first phase are studied in this phase and the system design is prepared. This system design helps in specifying hardware and system requirements and helps in defining the overall system architecture.

- Implementation - With inputs from the system design, the system is first developed in small programs called units, which are integrated in the next phase. Each unit is developed and tested for its functionality, which is referred to as Unit Testing.

- Integration and Testing - All the units developed in the implementation phase are integrated into a system after testing of each unit. Post integration the entire system is tested for any faults and failures.

- Deployment of system - Once the functional and non-functional testing is done; the product is deployed in the customer environment or released into the market.

- Maintenance - There are some issues which come up in the client environment. To fix those issues, patches are released. Also to enhance the product some better versions are released. Maintenance is done to deliver these changes in the customer environment. 


\section{RESEARCH RESULTS AND DISCUSSION}

This stage is an activity of making a system or application using the help of software and hardware in accordance with the analysis and design to produce a system that works.

Then an evaluation of the results of the trial is conducted, if the trial results have errors, then an improvement is made. This evaluation is carried out to determine whether the system formed in accordance with what is desired. After repairs and modifications made to the system, the system can be operated.

\section{Admin Login Display}

This display is a means of user login into the system to see the process carried out, on this page the user enters a username and password. The appearance can be seen drawn the following:
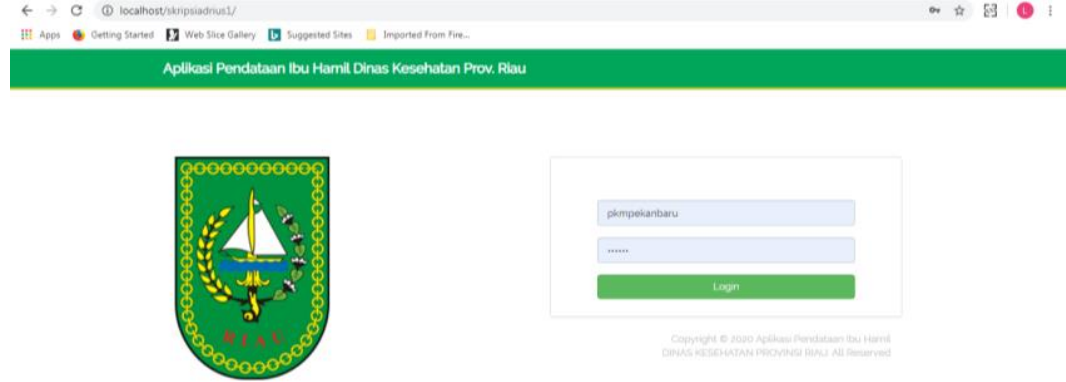

\section{Admin Dashboard}

Figure 2. Login Admin

Admin system dashboard display displays initial information, where the admin can see and filter the desired data categories.

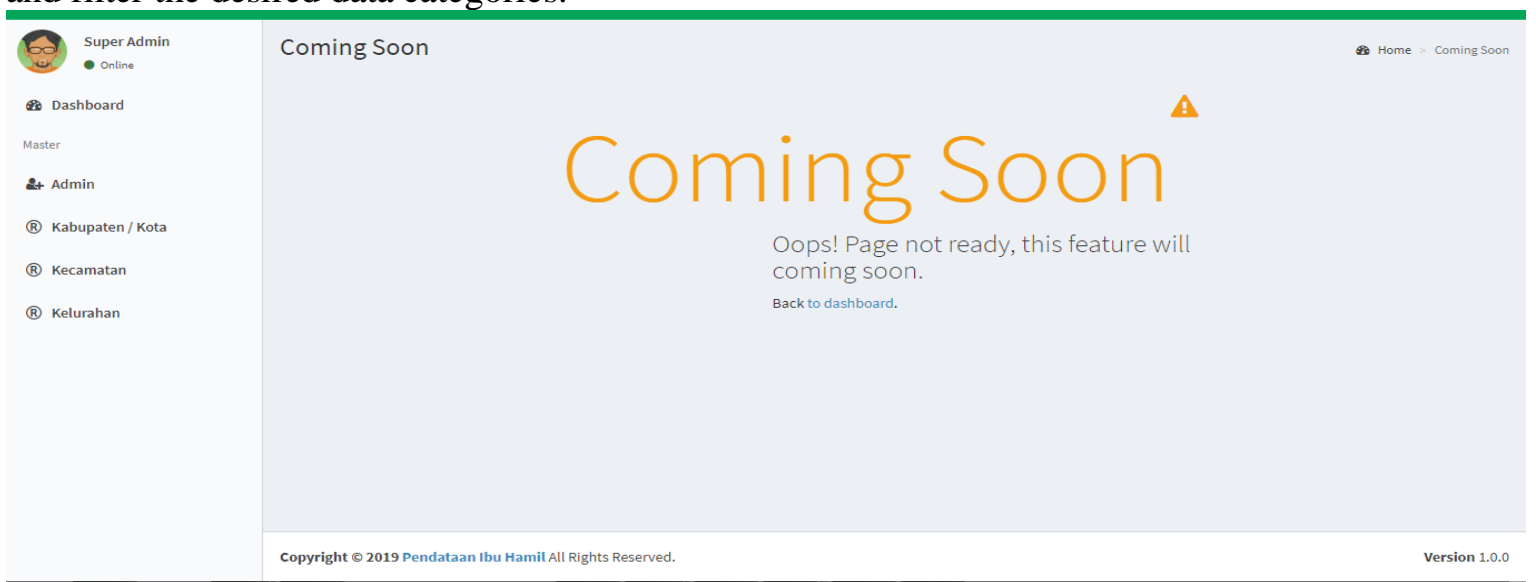

Figure 3. Main page admin

Main Display District / City Health Office

This page displays the Main Display District / City Health Office 


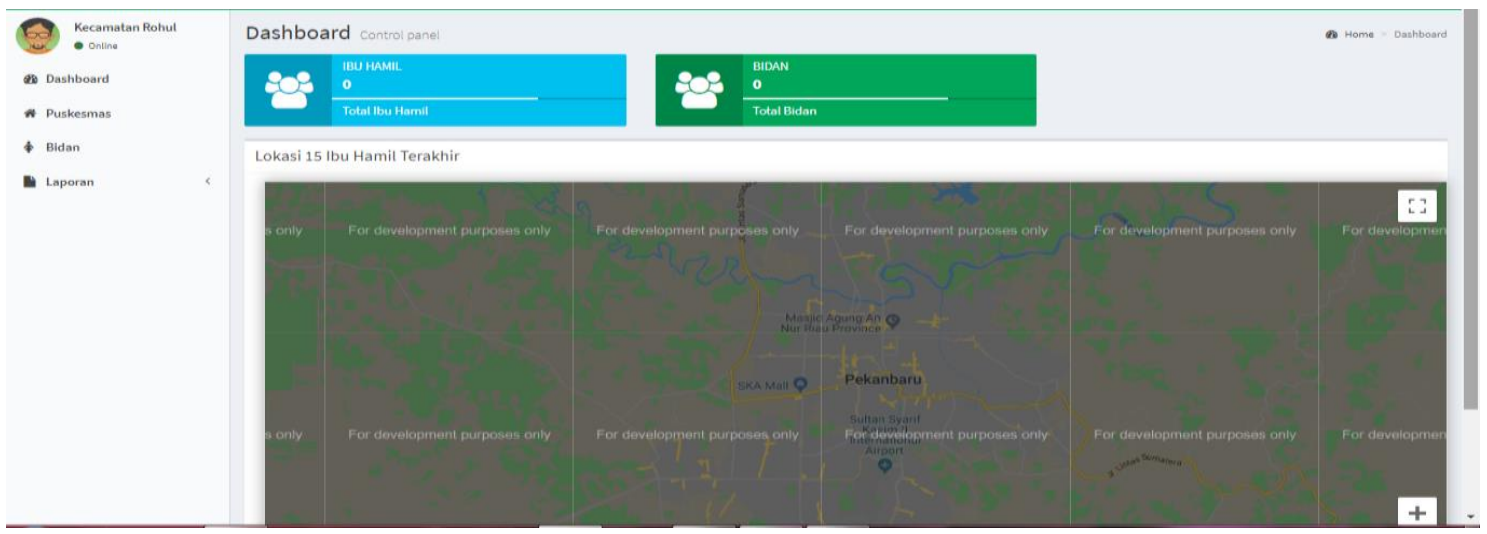

Figure. 4 Main Page District / City Health Service

\section{Report of Regency / City Pregnant Women}

This page displays the report on district / city pregnant women

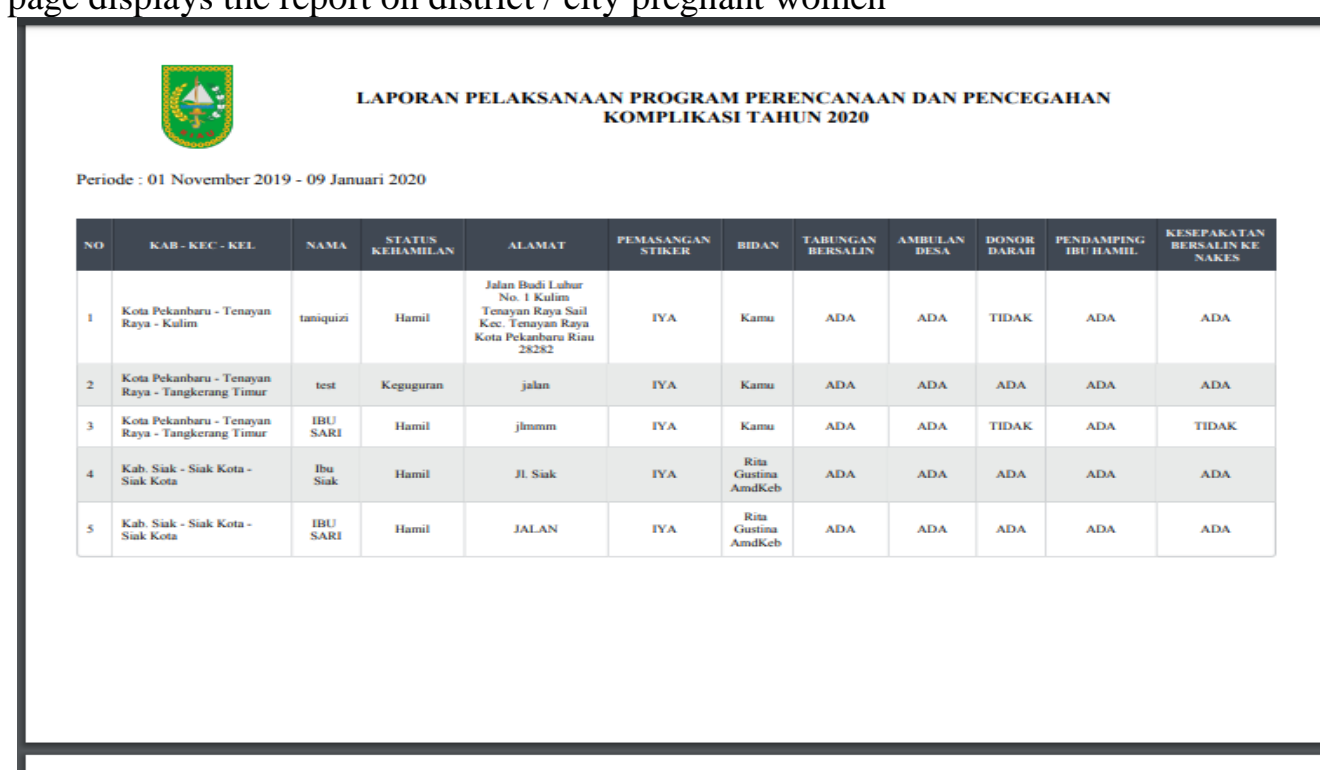

Figure. 5 Display District / City Pregnant Women Reports

\section{Main View of Puskesmas}

The main page in the application can be seen the Puskesmas has successfully logged in :

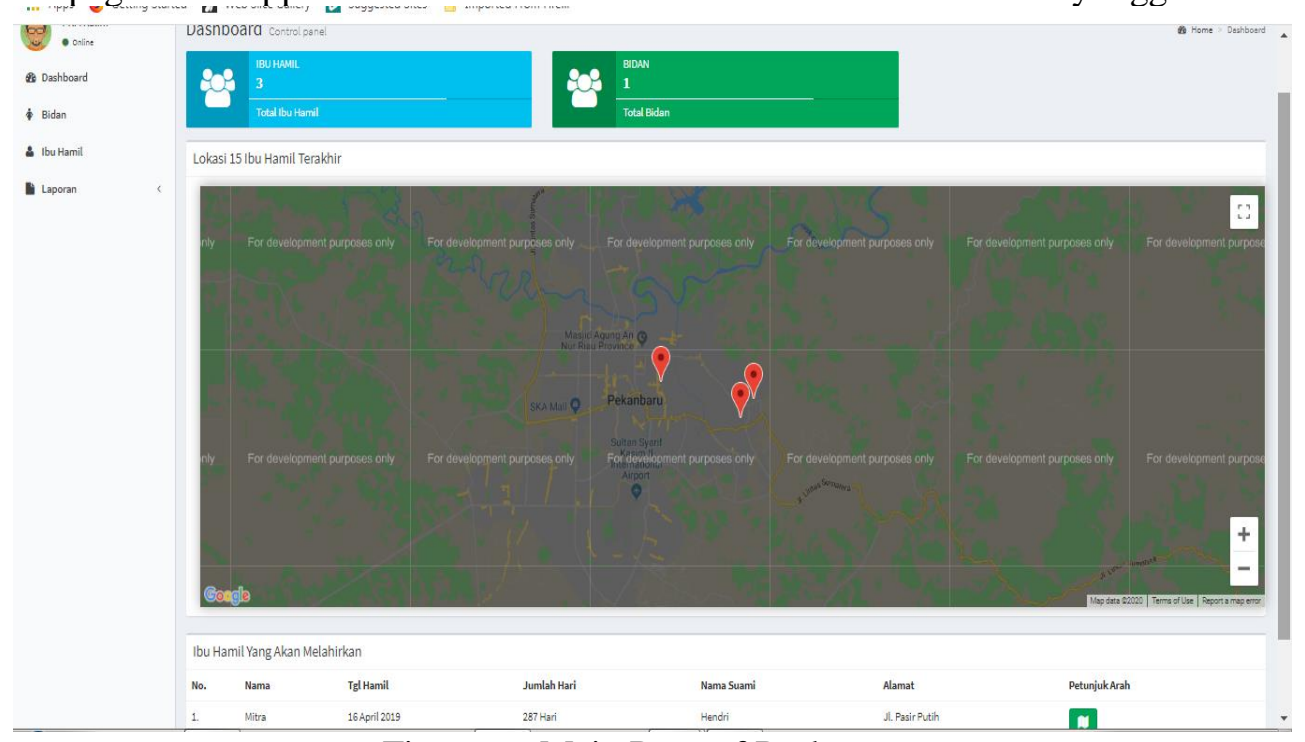

Figure. 6. Main Page of Puskesmas 


\section{Display Add Pregnant Women}

To be able to add data on Pregnant Women Health Monitoring Application for Pregnant Women, Puskesmas are required to have an account that has been registered into the database, if the account input is invalid then the system will automatically return to the initial page to reenter.

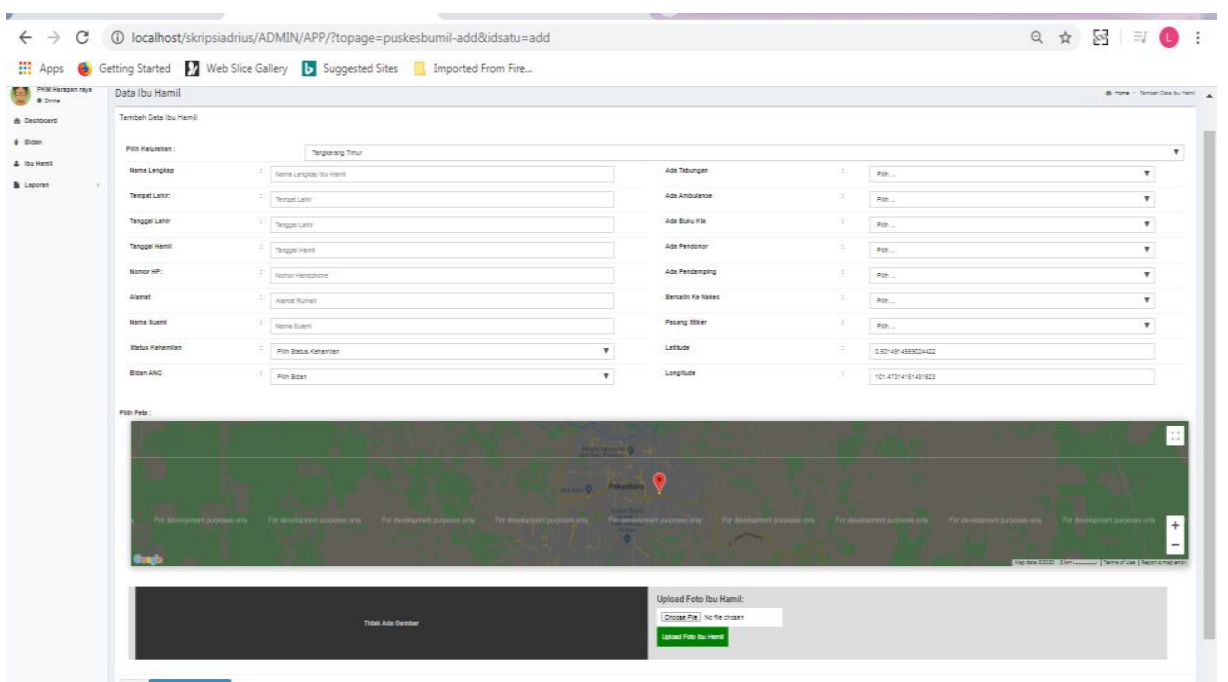

Figure 7. Display added Pregnant Women

Display of Recapitulation Reports of Pregnant Women in Puskesmas

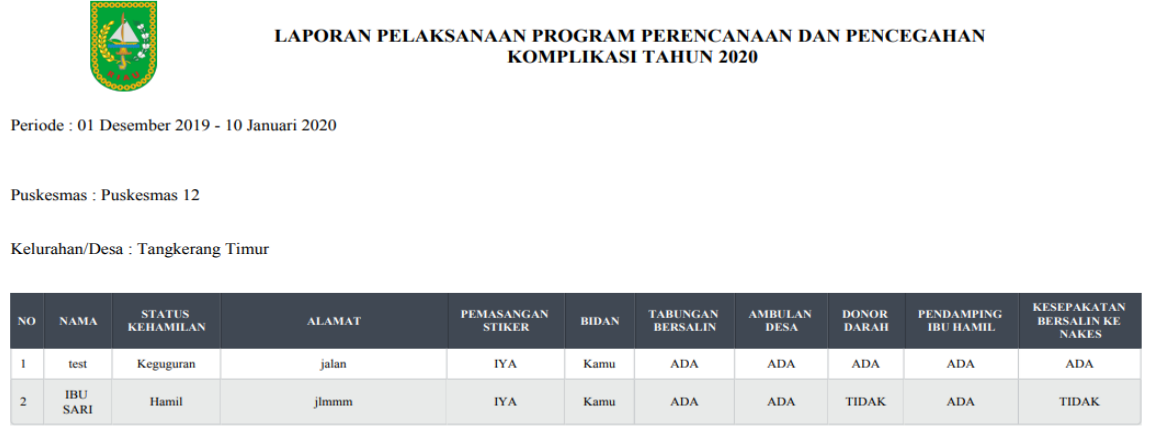

Figure 8. Display of Pregnant Women Reports at the Health Center

\section{CONCLUSIONS}

Based on the analysis and discussion as well as the description of the previous chapters, it can be concluded as follows:

1. Application for Monitoring Health of Pregnant Women at the Riau Provincial Health Service based on WebGis is expected to be able to solve the problem of building an Application for the Riau Provincial Health Service which is represented by officers in terms of conducting Monitoring of Pregnant Women's Health.

2. This application will facilitate officers in carrying out Health Monitoring for Pregnant Women, with the help of GPS and Google maps, the coordinates will be tracked where the location of Pregnant Women is.

3. This application can help provide accurate data where when Monitoring Health in accordance with the location of Pregnant Women.

4. This application can make it easier to find data on Pregnant Women in districts / cities, districts and villages / villages in Riau Province. 


\section{REFERENCES}

Darmawan, Deni \& Fauzi, K. N. (2013). Sistem Informasi Manajemen. Bandung : PT Remaja Rosda Karya.

Fadilah, N., \& McKenna, L. (2019). New nurses and community maternal care education: A qualitative study. Nurse education in practice, 34, 139-144.

Irawan, Y. (2017). Perencanaan Strategis Si/ti dengan Menggunakan Framework Ward And Peppard di STIKES Hang Tuah Pekanbaru. Jurnal Ilmu Komputer, 6(1), 25-32.

Indonesia, M. P., \& Kemiskinan, U. P. (2015). Understanding the Causes of Maternal Mortality in Indonesia.

Irawan, Y. (2017). Perencanaan Strategis Si/ti dengan Menggunakan Framework Ward And Peppard di STIKES Hang Tuah Pekanbaru. Jurnal Ilmu Komputer, 6(1), 25-32.

Kadir, A. (2014). Pengenalan Sistem Informasi. Andi. Yogyakarta.

Kamidah, K. (2018). Program Perencanaan Persalinan Dan Pencegahan Komplikasi (P4K) sebagai upaya menurunkan Angka Kematian Ibu. Gaster, 16(1), 24-35.

Sudirman, S. (2016). Aplikasi Panduan dan Monitoring Ibu Hamil Berbasis Android (Doctoral dissertation, Universitas Islam Negeri Alauddin Makassar). 